\title{
Loss of kidney function due to proteinuria, common problem with a rare cause: Question
}

\author{
Julia Steinke $^{1} \cdot$ Michaela Gessner $^{2} \cdot$ Leonie Frauenfeld ${ }^{1} \cdot$ Anna K Fischer $^{1} \cdot$ Wiebke Solass $^{1}$ \\ Received: 25 September 2019 / Revised: 6 February 2020 / Accepted: 11 February 2020 / Published online: 11 March 2020 \\ (C) The Author(s) 2020
}

\section{Case study}

We report a 12-year-old girl with a large unselective proteinuria since she was 7 years old. To delay the progression of proteinuria/renal impairment, medication with ramipril and candesartan was introduced and maintained for several years. Secondary complications of renal insufficiency, such as renal anemia, secondary hyperparathyroidism, and metabolic acidosis, were treated conservatively.

In addition, the patient had significant growth retardation ( $-3.53 \mathrm{SDS})$, myopia, and a mild aortic valve insufficiency. The developmental neurological examination was unremarkable.

However, when she was 12 years old, the consequences of proteinuria became unmanageable; she presented increasing edema and ascites (laboratory tests shown in Table 1). Attempts to stabilize the situation with albumin substitution and furosemide failed. She developed renal failure and a hemodialysis catheter was implanted. In the same session a nephrectomy of the left kidney was performed to minimize the loss of albumin. The day after nephrectomy, the proteinuria had halved (see image of nephrectomy specimen in Fig. 1 and histological results in Fig. 2). However, a few days after the initial operation she presented oligo-/anuresis. The remaining right kidney could not provide sufficient diuresis. Therefore, hemodialysis was started, maintained for 2 years (three times a week) before kidney transplantation was successfully performed. The then performed right-sided nephrectomy specimen showed the same macroscopic and histological changes as its counterpart.

The answers to these questions can be found at https://doi.org/10.1007/ s00467-020-04505-7.

Wiebke Solass

wiebke.solass@med.uni-tuebingen.de

1 Institute of Pathology and Neuropathology, University Hospital Tuebingen, Eberhard-Karls University Tuebingen,

Tuebingen, Germany

2 Department of Pediatric Nephrology, University Hospital Tuebingen, Eberhard-Karls University Tuebingen, Tuebingen, Germany 
Table 1 Laboratory results at hospital admission

\begin{tabular}{|c|c|c|c|}
\hline & Value & Range & Unit \\
\hline \multicolumn{4}{|l|}{ Laboratory blood test } \\
\hline Erythrocyte & 3.38 & $4.0-5.2$ & $\mathrm{Mio} / \mu \mathrm{l}$ \\
\hline Hematocrit & 24.8 & $37.0-47.0$ & $\%$ \\
\hline $\mathrm{HB}$ & 8.8 & $11.8-15.0$ & $\mathrm{~g} / \mathrm{dl}$ \\
\hline $\mathrm{MCH}$ & 26 & $27.0-34.0$ & pg \\
\hline $\mathrm{MCHC}$ & 35.5 & $32.0-36.0$ & $\mathrm{~g} / \mathrm{dl}$ \\
\hline $\mathrm{MCV}$ & 73.4 & $80-93$ & $\mathrm{fl}$ \\
\hline Sodium & 143 & $136-148$ & $\mathrm{mmol} / \mathrm{l}$ \\
\hline Potassium & 4.4 & $3.4-4.8$ & $\mathrm{mmol} / \mathrm{l}$ \\
\hline Calcium & 2.1 & $2.1-2.6$ & $\mathrm{mmol} / \mathrm{l}$ \\
\hline Phosphate anorganic & 2.0 & $1.3-1.8$ & $\mathrm{mmol} / \mathrm{l}$ \\
\hline Creatinine & 3.8 & $0.2-0.6$ & $\mathrm{mg} / \mathrm{dl}$ \\
\hline Urea & 180 & $10-35$ & $\mathrm{mg} / \mathrm{dl}$ \\
\hline Cystatin C & 3.4 & $0.5-1.0$ & $\mathrm{mg} / \mathrm{l}$ \\
\hline Protein total & 5.1 & $6-8$ & $\mathrm{~g} / \mathrm{dl}$ \\
\hline Albumin & 2.7 & $3.0-3.0$ & $\mathrm{~g} / \mathrm{dl}$ \\
\hline Cholesterin & 160 & 130-190 & $\mathrm{mg} / \mathrm{dl}$ \\
\hline Triglyceride & 213 & $\max .200$ & $\mathrm{mg} / \mathrm{dl}$ \\
\hline C-reactive protein & 0.04 & $\max .0 .05$ & $\mathrm{mg} / \mathrm{dl}$ \\
\hline PTH & 35.7 & $1.5-7.6$ & $\mathrm{pmol} / \mathrm{l}$ \\
\hline \multicolumn{4}{|l|}{ Laboratory urine test } \\
\hline Crea & 52 & & $\mathrm{mg} / \mathrm{dl}$ \\
\hline Protein & 13.1 & $\max .0 .1$ & $\mathrm{~g} / 1$ \\
\hline Quot. U-Protein/U-Crea & 25,192 & $\max .100$ & $\mathrm{mg} / \mathrm{gCrea}$ \\
\hline Albumin & 13,000 & $\max .20$ & $\mathrm{mg} / \mathrm{l}$ \\
\hline Quot. U-Alb./U-Crea & 25,000 & $\max .20$ & $\mathrm{mg} / \mathrm{gCrea}$ \\
\hline A1-Microglob./Crea & 148.1 & $\max .13$ & $\mathrm{mg} / \mathrm{gCrea}$ \\
\hline U-IgG/gCrea & 1271.2 & $\max .10$ & $\mathrm{mg} / \mathrm{gCrea}$ \\
\hline
\end{tabular}

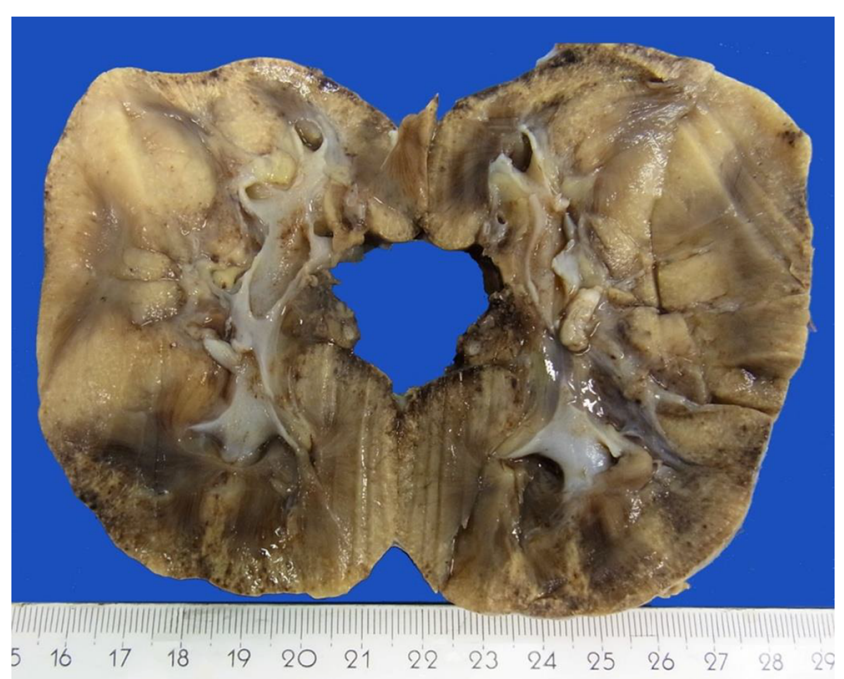

Fig. 1 Nephrectomy-specimen tangential sectioned; note the color changes between medulla and cortex; the lower and upper half of the kidney. Especially on the left upper half a pronounced yellowish discoloration of the tissue is noticed
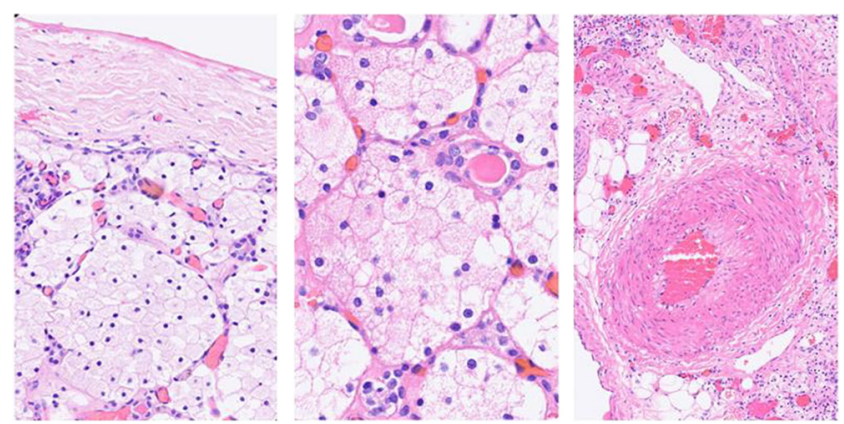

Fig. 2 Histological examination of the nephrectomy. Renal parenchyma with massive, interstitial accumulation of histiocytic macrophages with clear, fine coarse cytoplasm (middle). The foamy macrophages are preferentially located at the periphery of the organ (left). The renal vessels show regular architecture (right)

\section{Question}

What is the cause of the nephrotic syndrome in this patient?

Funding Information Open Access funding provided by Projekt DEAL.

\section{Compliance with ethical standards}

Conflict of interest The authors declare that they have no conflict of interest.

Open Access This article is licensed under a Creative Commons Attribution 4.0 International License, which permits use, sharing, adaptation, distribution and reproduction in any medium or format, as long as you give appropriate credit to the original author(s) and the source, provide a link to the Creative Commons licence, and indicate if changes were made. The images or other third party material in this article are included in the article's Creative Commons licence, unless indicated otherwise in a credit line to the material. If material is not included in the article's Creative Commons licence and your intended use is not permitted by statutory regulation or exceeds the permitted use, you will need to obtain permission directly from the copyright holder. To view a copy of this licence, visit http://creativecommons.org/licenses/by/4.0/.

Publisher's note Springer Nature remains neutral with regard to jurisdictional claims in published maps and institutional affiliations. 